\title{
Hughes-Stovin syndrome
}

INSERM

\section{Source}

INSERM. (1999). Orphanet: an online rare disease and orphan drug data base. HughesStovin syndrome. ORPHA:228116

Hughes-Stovin syndrome (HSS) is a life-threatening disorder, believed to be a cardiovascular clinical variant manifestation of Behçet's disease (BD; see this term). It is characterized by the association of multiple pulmonary artery aneurysms (PAAs) and peripheral venous thrombosis. 